\title{
Dissolution test optimization for meloxicam in the tablet pharmaceutical form
}

\author{
Érika de Fátima Silva Oliveira ${ }^{1}$, Roberta de Cássia Pimentel Azevedo ${ }^{1}$, Rudy Bonfilio ${ }^{1}$, Diego \\ Borges de Oliveira ${ }^{1}$, Gislaine Pereira Ribeiro ${ }^{2}$, Magali Benjamim de Araújo ${ }^{2 *}$
}

${ }^{1}$ Laboratory Quality Control Nucleus, Federal University of Alfenas, ${ }^{2}$ Department of Pharmacy, Federal University of Alfenas

\begin{abstract}
Meloxicam is a broadly used drug in the therapeutics for the osteoarthritis and rheumatoid arthritis treatments in adults, and it is available in the Brazilian market, as tablet and capsule pharmaceutical forms. The present work aimed to establish conditions for accomplishment of the dissolution test of 15 mg meloxicam tablets (A and B test products), compared with the reference product, since there is no monograph about dissolution assays for meloxicam in official summaries. To optimize the conditions several parameters were tested and, according to obtained results, the use of $\mathrm{pH} 7.5$ phosphate buffer $\left(900 \mathrm{~mL}\right.$, at $\left.37 \pm 0.5^{\circ} \mathrm{C}\right)$ as dissolution medium, paddle method (apparatus 2), stirring speed of the dissolution medium at $100 \mathrm{rpm}$ and collect time of 60 minutes were considered satisfactory. The samples were quantified by UV spectrophotometric method at $362 \mathrm{~nm}$. The products presented kinetics of firstorder. Dissolution efficiency values were of $83.25,83.73$ and $88.10 \%$ for the A, B and reference products, respectively. Factors $f_{1}$ and $f_{2}$ were calculated and similarity of the tested medicines was demonstrated. The dissolution test was validated presenting selectivity, linearity, precision and accuracy within of the acceptance criteria.
\end{abstract}

Uniterms: Meloxicam/dissolution. Dissolution kinetics. Tablet pharmaceutical forms/dissolution test. Spectrophotometry.

O meloxicam é fármaco amplamente utilizado na terapêutica para o tratamento de osteoartrite e artrite reumatóide em adultos, e encontra-se disponível no mercado brasileiro, sob as formas farmacêuticas comprimido e cápsula. $\mathrm{O}$ presente trabalho objetivou estabelecer condições para realização do teste de dissolução de meloxicam $15 \mathrm{mg}$ na forma farmacêutica comprimido (medicamentos-teste A e B), comparado com o medicamento de referência, visto que não há monografia para o ensaio de dissolução com meloxicam em compêndios oficiais. Para otimização das condições, diversos parâmetros foram testados e de acordo com os resultados obtidos, a utilização de tampão fosfato $\mathrm{pH} 7,5$ (900mL, a $37 \pm 0,5^{\circ} \mathrm{C}$ ) como meio de dissolução, aparato 2 (pá), velocidade de agitação do meio de dissolução de $100 \mathrm{rpm}$ e tempo de coleta em 60 minutos, foram considerados satisfatórios. As amostras foram quantificadas por espectrofotometria na região do ultravioleta, a $362 \mathrm{~nm}$. Os produtos apresentaram cinética de primeira ordem. Para a eficiência de dissolução encontraram-se valores de 83,25, 83,73 e $88,10 \%$ para os medicamentos-teste $\mathrm{A}$ e $\mathrm{B}$ e referência, respectivamente. Os fatores $\mathrm{f}_{1}$ e $\mathrm{f}_{2}$ foram calculados, demonstrando haver similaridade entre os medicamentos avaliados. O ensaio de dissolução foi validado apresentando seletividade, linearidade, precisão e exatidão dentro dos critérios de aceitação.

Unitermos: Meloxicam/dissolução. Cinética de dissolução. Comprimidos/teste de dissolução. Espectrofotometria.

\section{INTRODUCTION}

Drug absorption from solid pharmaceutical forms following oral administration depends on the stages of

\footnotetext{
*Correspondence: M. B. Araújo. Laboratório Núcleo Controle de Qualidade, Departamento de Farmácia, Universidade Federal de Alfenas - UNIFAL-MG, Rua Gabriel Monteiro da Silva, 700 - 37130.000 - Alfenas - MG, Brasil. E- mail:
} magali@unifal-mg.edu.br disintegration, disaggregation, drug release from the pharmaceutical form, its dissolution under physiological conditions and the permeability through the biological membranes (Abdou, 1995). Based on these considerations, in vitro dissolution test is a very important stage to predict the drug in vivo performance.

The bioavailability, which describes the rate and extent of active drug that is absorbed, may be altered by any 
factor that can change the disintegration and dissolution drug process (Storpirtis et al., 1999).

Dissolution profile compares the percentage of a drug substance dissolved relating to time (Abdou, 1995) and represents an alternative to assessment of solid pharmaceutical forms before clinical tests.

Regarding Biopharmaceutics Classification System (BCS), high permeability and low solubility drugs are grouped in class II. In this case, the dissolution profile must be quite definite and highly reproducible. Drug dissolution of this class is the limiting step for drug absorption. The appropriate comparison of drug product formulations in this category requires multiple point dissolution tests, in order to characterize the dissolution profile (Amidon et al., 1995; Brasil, 2004; Galia et al., 1998; Pillai, Dhanikula, Panchagnula, 2001). Establishment of an in vitro/in vivo correlation and the resulting ability to discriminate between formulations with different bioavailabilities will be dependent on how well the in vitro tests are designed (Dressman et al., 1998).

Meloxicam is a broadly used drug in the therapeutics for the osteoarthritis and rheumatoid arthritis treatments in adults. It is one of the few drugs considered "preferential" COX 2 inhibitors available in the pharmaceutical market, since in the last years some potentially selective drugs, such as rofecoxibe and valdecoxibe, were removed from the market due to the serious harmful effects that they might cause (Engelhardt et al., 1995; Food, 2006; Furst, Munster, 2003; Insel, 1996; Korolkovas, 2007).

Several pharmaceutical products containing meloxicam are commercialized in the Brazilian market as similar drugs in the tablet pharmaceutical form. They are very often interchanging with the reference drug product. Meloxicam is a yellow solid drug, practically insoluble in water, with higher solubility observed in strong bases. It is very slightly soluble in methanol. Meloxicam has an apparent partition coefficient $(\log \mathrm{P})$ app $=0.1$ in $n$-octanol/buffer $\mathrm{pH}$ 7.4. Meloxicam has $\mathrm{pKa}$ values of 1.1 and 4.2. It is, therefore, considered a class II drug (Final, 2006).

The aim of the present work was to establish experimental conditions, to validate the dissolution test for $15 \mathrm{mg}$ meloxicam in tablet pharmaceutical form and to compare the dissolution profiles obtained from different commercial products, using dissolution kinetic studies and dissolution efficiency methods.

\section{MATERIALS AND METHODS}

\section{Pharmaceutical specialties and chemical reference substance}

Two pharmaceutical specialties, obtained from the
Brazilian market in tablet pharmaceutical form, claiming to contain $15 \mathrm{mg}$ of meloxicam were tested. Two different laboratories supplied these products, which were codified as test product A (lot 50011, production date: 2005/01, expiration date: $2007 / 01$ ) and test product B (lot 880 , production date: $2005 / 05$, expiration date: 2008/05). Reference product Movatec ${ }^{\circledR}, 15 \mathrm{mg}$ tablets (lot 8222 , production date: 2006/09, expiration date: 2008/09) and meloxicam reference substance (declared content of $99.60 \%$ and expiration date: $2007 / 05$ ) were also used.

\section{Equipments}

The following equipments were used: Electrolab dissolution tester (model TDT-08 L) equipped with eight dissolution vessels; Unique ultrasonic Bath (model USC1400); Kern analytical balance (model 410); Nova Técnica vacuum filtration system; Shimadzu UV/VIS visible spectrophotometer (model 1601 PC); TKA - HPW water purifier system and Marconi digital $\mathrm{pHmeter} \mathrm{(model}$ PA 200).

\section{Optimization of dissolution test}

To establish the ideal experimental conditions it was used, initially, solutions of meloxicam reference substance in $\mathrm{pH}=6.8$ potassium phosphate buffer; $\mathrm{pH}=6.8$ potassium phosphate buffer, containing $0.01 \%$ sodium lauryl sulfate and $\mathrm{pH}=7.5$ potassium phosphate buffer. These solutions were prepared using the following reagents: potassium dihydrogenphosphate anhydrous PA (Vetec); sodium hydroxide PA (Vetec) and sodium lauryl sulfate PA (Vetec). Later, a spectral scanning was carried out in order to get the wavelength to be used in the drug quantification.

The optimized experimental conditions for obtaining the dissolution profiles of the $\mathrm{A}$ and $\mathrm{B}$ test products were established by using the reference product and the conditions are presented in Table I. The dissolution test was performed by removal of $15 \mathrm{~mL}$ samples of dissolution medium at 15 , 30, 45, 60, 75, 90 and 105 minutes, followed by dissolution medium replacement. The temperature of the dissolution medium was maintained at $37 \pm 0.5^{\circ} \mathrm{C}$. The concentration of dissolved meloxicam in the dissolution vessels, at predetermined time intervals, was determined by ultraviolet spectrophotometry in wavelength of $362 \mathrm{~nm}$ and was obtained by comparison with a standard solution of meloxicam reference substance containing a known concentration.

\section{Validation}

Dissolution test validation was performed accord- 
TABLE I - Established conditions for dissolution test optimization of meloxicam reference product in tablet pharmaceutical form

\begin{tabular}{cccc}
\hline Condition & Apparatus & Dissolution medium $(900 \mathrm{~mL})$ & Stirring speed (rpm) \\
\hline I & Paddle & $\mathrm{pH}=6.8$ potassium phosphate buffer & 50 \\
II & Paddle & $\mathrm{pH}=6.8$ potassium phosphate buffer & 75 \\
III & Paddle & $\mathrm{pH}=6.8$ potassium phosphate buffer & 100 \\
IV & Basket & $\mathrm{pH}=6.8$ potassium phosphate buffer & 50 \\
V & Basket & $\mathrm{PH}=6.8$ potassium phosphate buffer & 100 \\
VI & Paddle & $\mathrm{pH}=6.8$ potassium phosphate buffer $+0.01 \%$ sodium lauryl sulfate & 50 \\
VII & Paddle & $\mathrm{pH}=6.8$ potassium phosphate buffer $+0.01 \%$ sodium lauryl sulfate & 75 \\
VIII & Paddle & $\mathrm{pH}=6.8$ potassium phosphate buffer $+0.01 \%$ sodium lauryl sulfate & 100 \\
IX & Basket & $\mathrm{pH}=6.8$ potassium phosphate buffer $+0.01 \%$ sodium lauryl sulfate & 50 \\
X & Basket & $\mathrm{pH}=6.8$ potassium phosphate buffer $+0.01 \%$ sodium lauryl sulfate & 100 \\
XI & Paddle & $\mathrm{pH}=7.5$ potassium phosphate buffer & 50 \\
XII & Paddle & $\mathrm{pH}=7.5$ potassium phosphate buffer & 75 \\
XIII & Paddle & $\mathrm{pH}=7.5$ potassium phosphate buffer & 100 \\
XIV & Basket & $\mathrm{pH}=7.5$ potassium phosphate buffer & 50 \\
XV & Basket & $\mathrm{pH}=7.5$ potassium phosphate buffer & 100 \\
\hline
\end{tabular}

ing to ANVISA resolution RE no 899 (Brasil, 2003) and AOAC International (1995) requirements, by means of the analysis of selectivity, linearity, precision and accuracy parameters.

Selectivity was evaluated by means of the analysis of the absorption spectra of the meloxicam reference standard and placebo tablet samples of the A and B test products, respectively. The samples were prepared and submitted under the following dissolution test conditions: $900 \mathrm{~mL}$ of $\mathrm{pH}=7.5$ potassium phosphate buffer as dissolution medium, temperature of the batch maintained at 37 $\pm 0.5^{\circ} \mathrm{C}$, paddle apparatus and stirring speed of $100 \mathrm{rpm}$. Aliquots were collected at 60 minutes and then filtered in a quantitative filter paper

Linearity was established by means of the construction of the calibration curve using meloxicam reference standard solutions in the concentrations of $9,11,13,15$ e $17 \mathrm{mg} / \mathrm{L}$, prepared in $\mathrm{pH}=7.5$ potassium phosphate buffer.

The precision of the procedure was determined by repeated analyses $(n=12)$ for intra-day and intermediate precision, respectively, using tablet samples of the A, B and reference products containing meloxicam. The samples of each product were submitted to the dissolution test under the same conditions described in the selectivity.

Accuracy was determined by standard addition method. Known amounts of the chemical reference substance were added to the tablet samples of the A, B and reference products, respectively, during dissolution test of each product for obtaining three concentration levels of the calibration curve: 9, 13 e $17 \mathrm{mg} / \mathrm{L}$. Solutions were filtered in a quantitative filter paper and then analyzed by the proposed method. The study was carried out in triplicate and the percentage recoveries were calculated.

\section{Dissolution parameters}

To study the drug release kinetics a zero-order kinetic model by plotting the undissolved drug amount versus the time, and the first-order kinetic model by plotting the natural logarithm (ln) of the undissolved drug amount versus the time were used (El Yazigi, 1981; Nikolic et al., 1992). The kinetic parameters of the dissolution such as the dissolution rate constant $(\mathrm{k})$ and half-life of release $\left(t_{50 \%}\right)$ were calculated by using equations of a mathematical model that presented most significant correlation coefficient.

Dissolution efficiency (ED\%) was calculated by using the ratio between the area above the meloxicam dissolution curve (ASC) at the time interval between 0 and 60 minutes and the total area of the rectangle (ATR) (described by $100 \%$ dissolution in 60 minutes) (Khan, 1975). The results of ED\% values of the tested products were submitted to variance analysis (ANOVA). Tukey test was used in order to detect the existence of significant differences between the averages.

The comparison of the dissolution profiles obtained from the A, B and reference products was also carried 
out by means of the determination of the $f_{1}$ and $f_{2}$ factors (difference factor and similarity factor). The equivalence between two profiles is observed when $f_{l}$ values are between 0 and 15 and $f_{2}$ values are between 50 and 100 (Brasil, 2004; Moore, Flanner, 1996).

\section{RESULTS AND DISCUSSION}

The spectral profiles of meloxicam reference standard in $\mathrm{pH}=6.8$ potassium phosphate buffer, $\mathrm{pH}=6.8$ potassium phosphate buffer with $0.01 \%$ sodium lauryl sulfate and $\mathrm{pH}=7.5$ potassium phosphate buffer showed maximum drug absorption wavelength at $362 \mathrm{~nm}$. Therefore, this wavelength was used for the meloxicam quantification throughout the study.

Definition of the appropriate parameters for meloxicam tablets dissolution test was made by using the reference product (Table I). Different conditions were involved such as: dissolution medium composition, use of paddle and basket apparatuses and stirring speeds of 50 , 75 and $100 \mathrm{rpm}$. The results of the studies demonstrated that when phosphate buffer, $\mathrm{pH}=6.8$ or this medium with $0.01 \%$ sodium lauryl sulfate were employed as dissolution medium, paddle or basket as apparatus at the stirring speed of 50,75 or $100 \mathrm{rpm}$, the tablet dissolution was incomplete, with release percentage lower than $85 \%$ within 90 minutes, therefore, not satisfying the minimum requirements established by ANVISA(Brasil, 2004). On the other hand, the use of $\mathrm{pH}=7.5$ potassium phosphate buffer as dissolution medium and paddle as apparatus at the stirring speed of $100 \mathrm{rpm}$ yielded a satisfactory dissolution of the drug in the first 60 minutes of the test, with drug release higher than $85 \%$ (Figure 1).

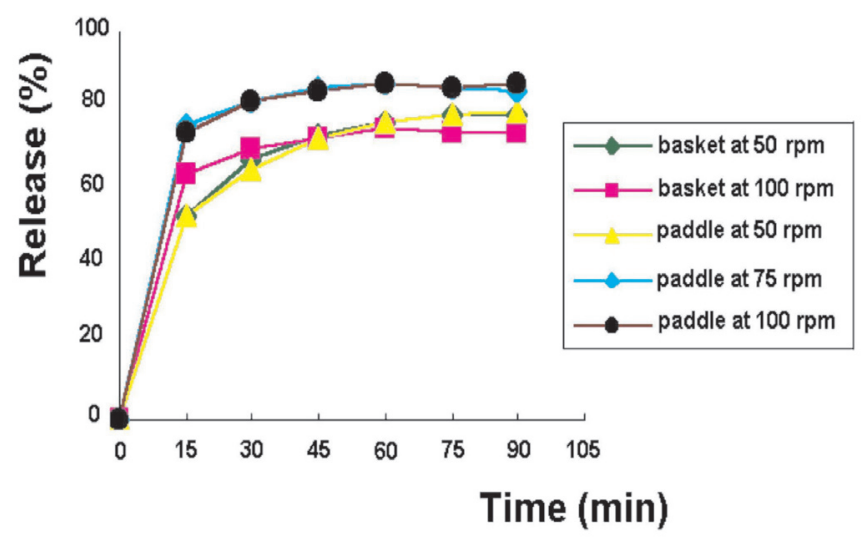

FIGURE 1- Dissolution profiles of $15 \mathrm{mg}$ meloxicam tablets (reference product) in $\mathrm{pH}=7.5$ potassium phosphate buffer at $37 \pm 0.5^{\circ} \mathrm{C}$, using different apparatuses and rotation speeds.
The results obtained from the matrix of the Table I, were optimized by means of the application of the Pareto analysis. The variables phosphate buffer $\mathrm{pH}=6.8$, rotation speed of dissolution medium at $50 \mathrm{rpm}$ and basket as apparatus were defined as the low level parameters. The variables phosphate buffer $\mathrm{pH}=7.5$, rotation speed of dissolution medium at $100 \mathrm{rpm}$ and paddle as apparatus were defined as the high level parameters.

Through combinatorial analysis, using the Pareto analysis at a $95.0 \%$ confidence level, it was possible to verify that optimal conditions are obtained with the use of $\mathrm{pH}=7.5$ phosphate buffer as dissolution medium, paddle as apparatus and dissolution medium rotation speed at $100 \mathrm{rpm}$. The interactions between variables are not statistically significant. Table II shows the levels used for accomplishment of the experimental design in a $2^{4}$ factorial design for application of the Pareto analysis. Figure 2 shows the Pareto chart used for the stablishment of the best conditions for accomplishment of dissolution profiles of meloxicam tablets.

TABLE II - Definition of the experimental levels of the variables used in the experimental design for $15 \mathrm{mg}$ meloxicam tablets, reference product

\begin{tabular}{lcc}
\hline Variable & Lower level & Upper level \\
\hline Apparatus & Basket & Paddle \\
\hline $\begin{array}{l}\text { Dissolution } \\
\text { medium }\end{array}$ & $\begin{array}{c}\text { Phosphate buffer } \\
\mathrm{pH}=6.8\end{array}$ & $\begin{array}{c}\text { Phosphate buffer } \\
\mathrm{pH}=7.5\end{array}$ \\
\hline $\begin{array}{l}\text { Rotation speed } \\
\text { (rpm) }\end{array}$ & 50 & 100 \\
\hline Time (min) & 45 & 60 \\
\hline
\end{tabular}

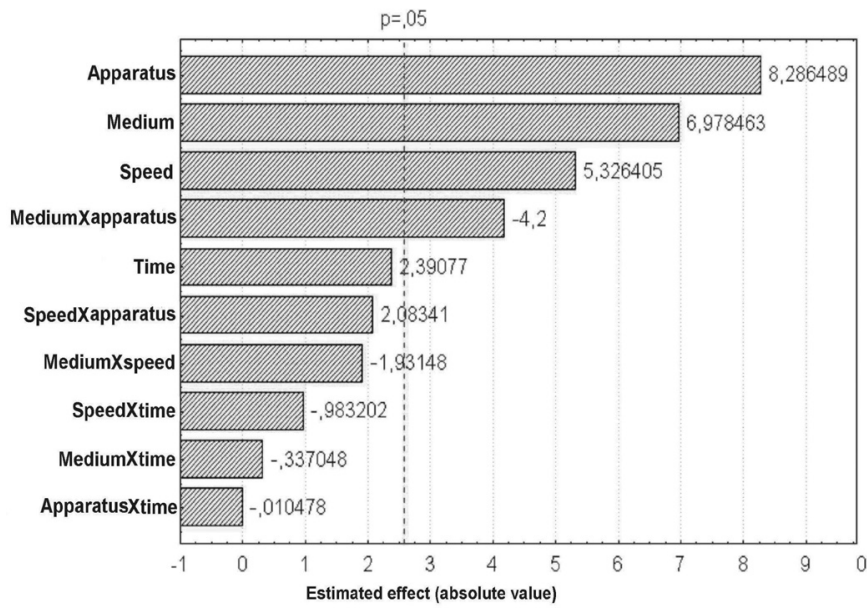

FIGURE 2- Pareto chart used for stablishment of the optimal conditions for accomplishment of dissolution profiles of $15 \mathrm{mg}$ meloxicam tablets. 
For validation of dissolution test it was verified, by the analysis of absorption spectra of the placebo tablet samples of products tests A and B, respectively, that formulation excipients did not interfere in the absorption spectra of the chemical reference substance.

Linearity was obtained in the concentration range 09-17 mg/L, with a correlation coefficient (r) of 0.9995 $(y=0.0457 x+0.0371)$. The estimation of relative standard deviation between determinations was smaller than $2 \%$, showing linear correlation between drug concentration and UV absorption.

Precision, evaluated under established conditions of the dissolution test, was determined by the relative standard deviation. For Intra-day precision, the overall relative standard deviations observed were $0.63 \%(n=12)$, $0.68 \%(\mathrm{n}=12)$ and $0.72 \%(\mathrm{n}=12)$ for the A, B and reference products, respectively. For intermediate precision, the overall relative standard deviation observed were $0.95 \%$ $(n=12), 1.20 \%(n=12)$, e $0.89 \%(n=12)$ for the A, B and reference products, respectively. These experimental results showed the good precision of the dissolution test when it is performed on the same and at different days. Relative standard deviations lower than or equal to $5 \%$ are considered acceptable (Brasil, 2003).

Accuracy was performed by standard addition method and evaluated by the recovery test. Known amounts of the meloxicam reference standard were added to the samples of the A, B and reference products during dissolution test. The mean recovery percentages of $98.09,97.98$ and $98.22 \%$ for the A, B and reference products, respectively, corroborating appropriate recovery. According to Marques, Brown (2002), values between 95.0-105.0\% are satisfactory.

Dissolution profiles are presented in Figure 3. The test products $\mathrm{A}$ and $\mathrm{B}$ showed homogeneous formulations, differing from the behavior of the reference product in the first 30 minutes. However, the kinetic parameters determination is important because they allow the comparative analysis of the in vitro behavior between the analyzed products. The analysis of variance (ANOVA) revealed a statistical difference $(p<0.05)$ between the products. The comparison between the optimized dissolution profiles was carried out using Tukey test, which demonstrated, with a level of significance of $5 \%$, a higher release percent for the reference product.

The study of drug release kinetics using the zeroorder and first-order kinetic models was performed. By means of the linearization of dissolution profiles the respective correlation coefficients (r) were obtained. The kinetic model considered more appropriate (the one which presented higher value of correlation coefficient) was the

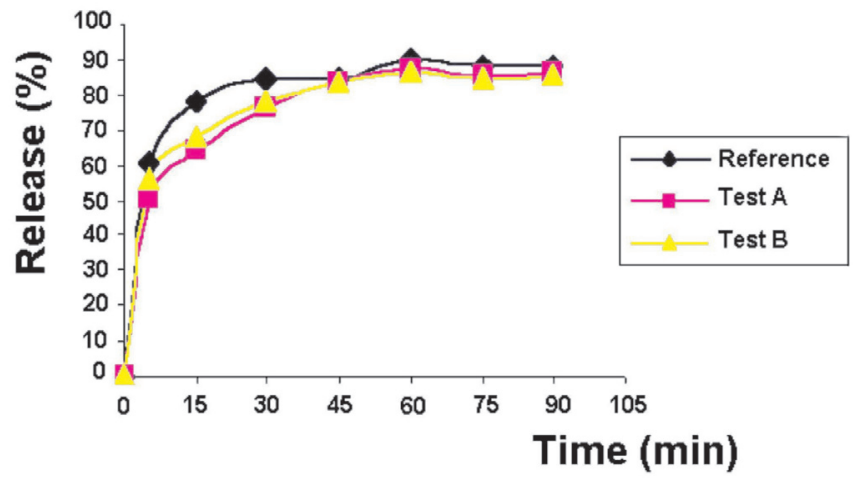

FIGURE 3- Dissolution profiles of $15 \mathrm{mg}$ meloxicam tablets obtained from A, B and reference products, respectively, using $\mathrm{pH}=7.5$ potassium phosphate buffer at $37 \pm 0.5^{\circ} \mathrm{C}$ as dissolution medium and paddle as apparatus at $100 \mathrm{rpm}$.

first-order model for all products (Table III). A first-order process of drug particle liberation is expected for conventional solid pharmaceutical forms (Ishi et al., 1996).

TABLE III - Statistical parameters from regression study using zero-order and first-order kinetic models. The parameters were obtained from dissolution profiles of the $\mathrm{A}, \mathrm{B}$ and reference products, respectively. Conditions: $\mathrm{pH}=7.5$ potassium phosphate buffer at $37 \pm 0.5^{\circ} \mathrm{C}$ as dissolution medium, paddle as apparatus at $100 \mathrm{rpm}$

\begin{tabular}{lcc}
\hline Model & Zero-order $(\mathrm{r})$ & First-order $(\mathrm{r})$ \\
\hline Test product A & 0.8716 & 0.8988 \\
Test product B & 0.8478 & 0.9325 \\
Reference product & 0.8974 & 0.9722 \\
\hline
\end{tabular}

The kinetic parameters of the dissolution test such as the dissolution rate constant $(\mathrm{k})$ and half-life of release $\left(\mathrm{t}_{50 \%}\right)$ were calculated by using the first-order kinetic model. Although the $\mathrm{k}$ values cannot be used for direct comparison of the profiles, its importance is related to the half-life of release $\left(\mathrm{t}_{50 \%}\right)$ calculation. Half-life of release $\left(t_{50 \%}\right)$ is of paramount importance because it establishes the time to promote the dissolution of $50 \%$ of the drug. The results indicated differentiated dissolution profiles for the analyzed products in the first 20 minutes. Therefore, the values of the half-life of the released product $\left(\mathrm{t}_{50 \%}\right)$ shown in Table IV demonstrate a good drug release performance for the analyzed products.

Dissolution efficiency (ED\%) also allows the comparison of drug dissolution profiles (Khan, 1975). (ED\%) is related with the real amount of drug dissolved in the dissolution medium and thus, lead to a better prognostic 
TABLE IV - Dissolution rate constant $(\mathrm{k})$ and half-life of release $\left(\mathrm{t}_{50 \%}\right)$ values for $\mathrm{A}, \mathrm{B}$ and reference products, respectively. Conditions: potassium phosphate buffer $\mathrm{pH}=7.5$ at $37 \pm 0.5^{\circ} \mathrm{C}$ as dissolution medium, paddle as apparatus at $100 \mathrm{rpm}$

\begin{tabular}{lcc}
\hline Model & $\mathrm{t}_{50 \%}(\mathrm{~min})$ & $\mathrm{k}\left(\mathrm{min}^{-1}\right)$ \\
\hline Test product A & 7.22 & 0.096 \\
Test product B & 8.06 & 0.086 \\
Reference product & 8.55 & 0.081 \\
\hline
\end{tabular}

for in vivo performance. (ED\%) results are shown in Table $\mathrm{V}$. The analysis of variance (ANOVA) revealed a statistical difference $(\mathrm{p}<0.05)$ between the products. Tukey test demonstrated that $\mathrm{A}$ and $\mathrm{B}$ test products presented significantly smaller values of ED\%, respectively, $(\mathrm{p}<0.05)$.

TABLE V - Dissolution efficiency (ED\%) values obtained from dissolution profiles of the A, B and reference products, respectively. Conditions: $\mathrm{pH}=7.5$ potassium phosphate buffer at $37 \pm 0.5^{\circ} \mathrm{C}$ as dissolution medium, paddle as apparatus at $100 \mathrm{rpm}$

\begin{tabular}{lccc}
\hline Parameter & $\begin{array}{c}\text { Test } \\
\text { product A }\end{array}$ & $\begin{array}{c}\text { Test } \\
\text { product B }\end{array}$ & $\begin{array}{c}\text { Reference } \\
\text { product }\end{array}$ \\
\hline ED (\%) & 83.25 & 83.73 & 88.10 \\
\hline
\end{tabular}

Values represent the mean of six determinations.

The $f_{1}$ and $f_{2}$ factors were calculated based on literature data (Brasil, 2004; Moore, Flanner, 1996). The obtained results showed similarity between dissolution profiles of the A, B and reference products. Dissolution profile comparison between test product $\mathrm{A}$ and reference product yield $f_{1}$ of 8.63 and $f_{2}$ of 77.54. Dissolution profile comparison between test product $\mathrm{B}$ and reference product yield $f_{1}$ of 8.44 and $f_{2}$ of 81.20 . All obtained values are within the specifications.

\section{CONCLUSIONS}

The optimal conditions for accomplishment of the dissolution test for meloxicam tablets were: $900 \mathrm{~mL}$ of $\mathrm{pH}$ 7.5 phosphate buffer at $37 \pm 0.5^{\circ} \mathrm{C}$ as dissolution medium, apparatus 2 (paddle) at the stirring speed of $100 \mathrm{rpm}$ and collect time in 60 minutes.

The validation showed that the dissolution test is appropriate for quantification of meloxicam in tablet pharmaceutical form for in vitro studies, presenting selectivity, linearity, precision and accuracy.

The experimental dissolution profiles of tested products follow first-order kinetics. Based on the dissolution kinetic parameters $\left(\mathrm{k}, \mathrm{t}_{50 \%}\right.$ and $\left.\mathrm{ED} \%\right)$ it was verified that the analyzed products presented dissolution profiles statistically different regarding the drug release percent of the pharmaceutical form. Nevertheless, the $f_{1}$ and $f_{2}$ results showed similarity between dissolution profiles of the A, B and reference products. For definite conclusions about the bioavailability and bioequivalence of these products, it is necessary the accomplishment of in vivo studies.

\section{ACKNOWLEDGEMENTS}

The authors thank FAPEMIG and PROBIC/ UNIFAL-MG program for financial support conceded to graduate and scientific initiation students, respectively, and to the companies that supplied the test products A and B.

\section{REFERENCES}

ABDOU, H. M. Dissolution. In: REMINGTON'S pharmaceutical sciences. 19. ed. Easton: Mack, 1995. p.593-604.

AMIDON, G. L.; LENNERNÄS, H.; SHAH, V. P.; CRISON, J.R. A theoretical basis for a biopharmaceutic drug classification: the correlation of in vitro drug product dissolution and in vivo bioavailability. Pharm. Res. New York, v.12, n.3, p.413-420, 1995.

ASSOCIATION OF OFFICIAL ANALYTICAL CHEMISTS. Official methods of analysis of AOAC international. 16.ed. Arlington: AOAC, 1995. v.1, pt.1. p. xviii.

BRASIL. Agência Nacional de Vigilância Sanitária. Resolução $\operatorname{RE} n^{\circ} 310,1^{\circ}$ de setembro de 2004, Guia para realização do estudo e elaboração do relatório de equivalência farmacêutica e perfil de dissolução, Diário Oficial da União, Brasília, 03 set. 2004. 5p. Available at: <http://www.anvisa. gov.br>. Access on: March 20th. 2007.

BRASIL. Agência Nacional de Vigilância Sanitária. Resolução RE nº89, 29 de maio de 2003, Guia para validação de métodos analíticos e bioanalíticos. Diário Oficial da União, Brasília, 02 jun. 2003 16p. Available at: <http://www. anvisa.gov.br>. Access on: April 14th. 2007.

DRESSMAN, J. B.; AMIDON, G. L.; REPPAS, C.; SHAH, V. P. Dissolution testing as prognostic tool for oral drug absorption: immediate release dosage forms. Pharm. Res., New York, v.15, n.1, p.11-22, 1998.

EL-YAZIGI, A. Disintegration: dissolution analysis of percent dissolved time data. J. Pharm. Sci., New York, v.70, n.5, p.535-537, 1981. 
ENGELHARDT, G.; HOMMA, D.; SCHLEGEL, K.; UTZMANN R.; SCHNITZLER, C.; Anti-inflammatory, analgesic, antipyretic and related properties of meloxicam, a new non-steroidal anti-inflammatory agent with favorable gastrointestinal tolerance. Inflamm. Res., v.44, n.10, p.423433,1995

FINAL DRAFT LABELING Mobic, 2000. Available at: <http: // www. fda.gov/ cder/foi/label/200/20938 lbl.pdf> Access on: May 10th. 2006.

FOOD AND DRUG ADMINISTRATION - FDA. Center for drug evaluation and research-CDER. Consumer information sheet meloxicam (marketed as Mobic). Available at: $<$ http:// www.fda.gov/cder/consumerinfo/druginfo/mobic.htm $>$. Access on: May 20th. 2006.

FURST, D. E.; MUNSTER, T. Antiinflamatórios não-esteróides, agentes anti-reumáticos modificadores da doença, analgésicos não opióides e drogas utilizadas na gota. In: KATZUNG, B. G. 8.ed. Farmacologia básica e clínica. Rio de Janeiro: Guanabara Koogan, 2003. cap.36, p.519-535.

GALIA, E.; NICOLAIDES, E.; HORTER, D.; LÖBENGER, R.; REPPAS, C.; DRESSMAN, J.B. Evaluation of various dissolution media for predicting in vivo performance of class I and II drugs. Pharm. Res., New York, v.15, n.5, p.698-705, 1998.

INSEL, P. A. Fármacos analgésico-antipiréticos e antiinflamatórios e medicamentos usados no tratamento da gota. In: GOODMAN GILMAN, A. As bases farmacológicas da terapêtica. 9. ed. México: Mc Graw Hill Interamericana Editora, 1996. cap.27, p.450-479.
ISHI, K.; SAITOU, R.; YAMADA, R.; ITAI, S.; NEMOTO, M. Novel approach determination of correlation between in vivo and in vitro dissolution using the optimization technique. Chem. Pharm. Bull., Tokyo, v. 44, n.8, p.15501555, 1996.

KHAN, K. A. The concept of dissolution efficiency. J. Pharm. Pharmacol., Wallingford, v.27, n.1, p.48-49, 1975.

KOROLKOVAS, A. Dicionário terapêutico guanabara. Rio de Janeiro: Guanabara Koogan, 2007. p.21.7.

MARQUES, M. R. C, BROWN, W. Desenvolvimento e validação de métodos de dissolução para formas farmacêuticas sólidas orais. Rev. Analytica, São Paulo, v.1, n.1, p.48-51, 2002.

MOORE, J. W.; FLANNER, H.H., Mathematical comparison of dissolution profiles. Pharm. Technol., São Paulo, v. 20, n. 6, p. 64-74, 1996.

NIKOLIC, L.; DJURIC, Z.; JOVANOVIC, M. Influence of in vitro test conditions on release of aspirin from commercial tablets. J. Pharm. Sci. Washington, v.81, n.4, p.386-391, 1992.

PILLAI, O.; DHANIKULA, A.B.; PANCHAGNULA, R. Drug delivery: odyssey of 100 years. Cur. Opin. Chem. Biol., Punjab, v.5, n.4, p.439-446, 2001.

STORPIRTIS, S.; OLIVEIRA, P.G.; RODRIGUES, D.; MARANHO, D. Considerações biofarmacotécnicas relevantes na fabricação de medicamentos genéricos: fatores que afetam a dissolução e a absorção de fármacos: Rev. Bras. Cien. Farm., São Paulo, v.35, n.1, p.1-16, 1999.

Recebido para publicação em 01 de novembro de 2007. Aceito para publicação em 10 de novembro de 2008 . 